\title{
Infectious pancreatic necrosis virus infection in Atlantic salmon Salmo salar post-smolts affects the outcome of secondary infections with infectious salmon anaemia virus or Vibrio salmonicida
}

\author{
Lill-Heidi Johansen*, Ann-Inger Sommer \\ Norwegian Institute of Fisheries and Aquaculture AS, Muninbakken 9, 9291 Tromsø, Norway
}

\begin{abstract}
Infectious pancreatic necrosis (IPN) virus (IPNV) infection in Atlantic salmon Salmo salar L. post-smolts and its influence on the outcome of secondary infections with infectious salmon anaemia (ISA) virus (ISAV) or Vibrio salmonicida were studied. The infections with ISAV or $V$. salmonicida were performed both in a period of acute IPN and in the following IPNV carrier stage, 3 and 6 to 8 wk after experimental IPNV challenge, respectively. An IPNV carrier condition at low virus titre did not influence the mortality rates after secondary infections. Neither the ISAV infection nor the $V$. salmonicida infection in experimentally induced IPNV carriers resulted in mortalities different from those observed after challenge of IPNV-free fish. At higher IPNV titres in Atlantic salmon with acute IPN, the outcome of secondary infections was quite different from that observed in IPNVfree fish and in IPNV carriers. In 2 different experiments significantly more fish died when fish with acute IPN were infected with $V$. salmonicida than when fish were infected with $V$. salmonicida alone. Mortality also started earlier in the double-infected group than in the group challenged with $V$. salmonicida alone, 3 to 4 and $8 \mathrm{~d}$ after $V$. salmonicida infection, respectively. Similar results were observed independent of whether mortalities due to IPN alone were registered in the experiments. When Atlantic salmon with acute IPN were infected with ISAV, significantly fewer fish died than when fish were infected with ISAV alone. The ongoing IPNV infection seemed to provide some protection against development of ISA.
\end{abstract}

KEY WORDS: Infectious pancreatic necrosis virus · IPNV · Atlantic salmon · IPNV carriers · Coinfection · Vibrio salmonicida · Infectious salmon anaemia virus

\section{INTRODUCTION}

Infectious pancreatic necrosis (IPN) virus (IPNV) is known to cause acute IPN in young hatchery-reared salmonids (Snieszko et al. 1959, Dorson \& Torchy 1981). Natural outbreaks of IPN in older salmonids have also been reported (Roberts \& McKnight 1976, Krogsrud et al. 1989, Smail et al. 1992). In Norway, farmed Atlantic salmon Salmo salar L. carrying the virus are very common (Melby et al. 1991), and the dis-

*E-mail: lill-heidi.johansen@fiskforsk.norut.no ease has become a significant contributor to post-smolt mortalities (Jarp et al. 1994). Because of the common situation with asymptomatic virus carriers, there is a great possibility that IPNV occasionally co-exists with other pathogens in the fish. Some reports describe natural double infections with IPNV and other viruses or bacteria in rainbow trout Oncorhynchus mykiss (Mulchahy \& Fryer 1976, La Patra et al. 1993, Evensen \& Lorenzen 1997). Viral interference between several fish viruses has been shown experimentally. Young rainbow trout infected with IPNV and later exposed to viral haemorrhagic septicaemia virus or infectious haematopoietic necrosis virus (IHNV) showed greater 
survival than parallel groups of trout not previously infected with IPNV (de Kinkelin et al. 1992). Furthermore, protection against IHNV in juvenile rainbow trout was registered for $4 \mathrm{wk}$ after a cutthroat trout virus (CTV) infection (Hedrick et al.1994), while resistance to IHNV lasted up to 8 wk after a chum salmon reovirus (CSV) infection (La Patra et al. 1995). Reports on the interaction between viruses and bacteria in experimentally infected fish are rather few, but recently Lee et al. (1999) reported double infections with IPNV and Vibrio carchariae in grouper Epinephelus sp. No mortality was registered in fish experimentally infected with IPNV or $V$. carchariae alone. Only double-infected fish died, suggesting a mutual role of the 2 pathogens in disease development.

There is still little knowledge about what influence an IPNV carrier condition may have on the general health of Atlantic salmon and the development of diseases. We have studied experimental IPNV infections in Atlantic salmon and potential influences on the outcome of both a viral and a bacterial secondary infection. To our knowledge this is the first report comparing the role acute IPN or an IPNV carrier condition may play in the development of secondary diseases. The present study shows how IPNV infections may interfere with infectious salmon anaemia (ISA) virus (ISAV) or Vibrio salmonicida infections in smoltified Atlantic salmon after transfer to seawater. ISAV is an aquatic orthomyxovirus causing ISA (Mjaaland et al. 1997, Sommer \& Mennen 1997). ISA has been a problem in farmed salmon in Norway for many years and recently the disease has been detected in farmed salmon in Scotland and Canada (Lovely et al. 1999, Rowley et al. 1999). V. salmonicida causes cold water vibriosis, which is a disease well known to the salmon farming industry.

\section{MATERIALS AND METHODS}

Challenge material, propagation and titration. IPNV: Whole fry collected during an outbreak of IPN on the west coast of Norway were kindly provided by Torunn Taksdal (Central Veterinary Laboratory, Oslo, Norway). The fry were homogenated in phosphate buffered saline to a final dilution of $5 \%(\mathrm{w} / \mathrm{v})$ and sonicated on ice for $1 \mathrm{~min}$. After centrifugation at $2000 \times \mathrm{g}$ for $10 \mathrm{~min}$ at $4^{\circ} \mathrm{C}$, the supernatants were harvested and filtered through a $0.8 \mu \mathrm{m}$ sterile filter and then through a sterile $0.22 \mu \mathrm{m}$ filter (Millipore). The isolated IPNV, of the Sp serotype, was used in all experiments after one passage in the Chinook salmon embryo (CHSE)-214 cell line. Monolayer cultures of CHSE-214 cell line (Lannan et al. 1984) were used for IPNV propagation, titration and virological examinations. The cells were cultured at $20^{\circ} \mathrm{C}$ in $175 \mathrm{~cm}^{2}$ tissue culture flasks (Nunclon) containing Eagle's minimum essential medium (EMEM, Gibco) supplemented with antibiotics, 1\% non-essential amino acids, $200 \mathrm{mM}$ L-glutamine and $8 \%$ foetal calf serum (FCS, HyClone). For virus propagation the FCS content was reduced to $2 \%$. The IPNV isolate to be used for challenge was added at a multiplicity of infection of 0.1 and incubated until a complete cytopathic effect (CPE) as evident. The infected cell cultures were kept frozen at $-80^{\circ} \mathrm{C}$ until the day of challenge. They were then thawed and the supernatant was centrifuged for $15 \mathrm{~min}$ at $2000 \times g$ at $4^{\circ} \mathrm{C}$ to remove cell debris and kept on ice until challenge. A small aliquot of the material was frozen separately and was used for determination of $\mathrm{TCID}_{50}(50 \%$ tissue culture infective dose) by end-point dilution (Reed \& Muench 1938) in 8 parallels on CHSE-214 cells in 96well plates (Nunclon). Harvested cell culture medium from uninfected cell cultures was used for mock infection of control fish.

ISAV: The ISAV used in all our experiments were originally isolated from an ISA outbreak in 1992 on the west coast of Norway. This material has later been used as original material and after reisolation in several experiments. Pooled tissue homogenate of kidney, liver and spleen $(5 \% \mathrm{w} / \mathrm{v}$ in phosphate buffered saline, PBS) collected from moribund ISAV-infected Atlantic salmon was used in Expt 1. The tissue homogenate containing ISAV was tested and found negative for IPNV in 3 passages in CHSE-214 cells. After a prechallenge experiment with different dilutions of this material, the concentration giving approximately $50 \%$ cumulative mortality was chosen. A plasma pool collected from fish in the early acute phase of experimentally induced ISA was used for cell culture production of ISAV for Expt 3. The viruses in the plasma pool were crudely purified and concentrated by ultracentrifugation on a discontinuous $30 \%$ over $60 \%$ sucrose gradient before addition to the Atlantic salmon (AS) cell line (Nicholson \& Byrne 1973). The second passage of ISAV propagated in the AS cells (ISAV02/97) was used in Expt 3 . The material contained $5 \times 10^{4}$ infectious particles $\mathrm{ml}^{-1}$, determined by use of haemadsorption centre assay (HACA) (Sommer \& Mennen 1997). A 1:10 dilution of this material, giving acute ISA with approximately $90 \%$ cumulative mortality in prechallenges, was used for challenge.

Vibrio salmonicida: Strain NCMB 2262, reisolated from Atlantic salmon, was grown for $48 \mathrm{~h}$ at $12^{\circ} \mathrm{C}$ on an orbital shaker in $125 \mathrm{ml}$ flasks containing $25 \mathrm{ml}$ marine broth (Difco) supplemented with $1 \% \mathrm{NaCl}$. Bacteria were centrifuged and resuspended in $0.9 \% \mathrm{NaCl}$ before use. Before each of Expts 1 and 2, three 10-fold dilutions of $V$. salmonicida suspensions were tested in prechallenges. The dilution of $V$. salmonicida giving a 
cumulative mortality of about $50 \%$ was used for challenge.

IPNV carrier tests. About $3 \%$ of each new batch of unchallenged fish was tested for IPNV carriers $6 \mathrm{wk}$ before, at the start of, and at the end of each of the 3 experiments, according to Hetrick (1989). Head kidneys were homogenated and seeded onto CHSE-214 cells in $25 \mathrm{~cm}^{2}$ cell culture flasks (Nunclon). Samples from 2 individuals were seeded in each flask. Three blind passages were done and no IPNV-positive pools were found (i.e., containing $<20$ infectious particles $\mathrm{g}^{-1}$ tissue, which was the lower detection level).

Challenge experiments. The effects of an acute or a persistent IPNV infection on the mortality following secondary infections with ISAV or Vibrio salmonicida were examined in 3 separate experiments. Unvaccinated Atlantic salmon of the Norwegian NLA (Norsk Lakseavl, Sunndalsøra, Norway) stock, hatcheryreared at the Aquaculture Research Station AS in Tromsø, Norway, were used. Before the experiments the fish were kept under ordinary production conditions in running fresh water and they were fed commercial dry feed (Skretting, Stavanger, Norway). The fish were subjected to a temperature of $7^{\circ} \mathrm{C}$ and continuous light $6 \mathrm{wk}$ before transfer to seawater. The smoltification process was monitored by $24 \mathrm{~h}$ seawater challenge tests (Blackburn \& Clarke 1987) to ensure that the fish were optimally smoltified at their transfer to seawater.

Previous experiments in our laboratory have shown that after an experimental IPNV infection the virus titres increase and reach a maximum of $10^{5}$ to $10^{8}$ $\mathrm{TCID}_{50} \mathrm{~g}^{-1}$ tissue 3 to $4 \mathrm{wk}$ after infection. The titres then decrease to about $10^{2}$ to $10^{4} \mathrm{TCID}_{50} \mathrm{~g}^{-1}$ tissue 6 to $8 \mathrm{wk}$ after infection (authors' unpubl. results). Thus, the secondary infections were performed both in a period of acute IPN and in the following IPNV carrier stage, 3 and 6 to 8 wk after experimental IPNV challenge, respectively. All experiments were run until mortality started in the non-inoculated cohabitant groups. In Expt 1, 340 smolts with an average weight of $50 \mathrm{~g}$ were transferred to seawater and bath challenged for $4 \mathrm{~h}$ with IPNV at a titre of $10^{4.85} \mathrm{TCID}_{50} \mathrm{ml}^{-1}$. The same number of smolts was mock infected in a separate tank with harvested cell culture medium from non-infected cell cultures. The experiment was run for $13 \mathrm{wk}$. One, 2, 3 and $6 \mathrm{wk}$ after IPNV challenge, 6 IPNV-infected and 6 uninfected fish were killed and head kidneys sampled and frozen at $-80^{\circ} \mathrm{C}$ for later IPNV titre tests. The lower IPNV detection level was $10^{2.25} \mathrm{TCID}_{50} \mathrm{~g}^{-1}$ tissue. IPNV titres were also determined in head kidney homogenates from dead fish. Three weeks after IPNV challenge, 60 IPNV infected and 60 uninfected post-smolts were injected intraperitoneally (i.p.) with $5 \times 10^{5}$ Vibrio salmonicida $(0.5 \mathrm{ml})$ per fish. The same number of fish was inoculated i.p. with $0.5 \mathrm{ml}(0.5 \% \mathrm{w} / \mathrm{v})$ tissue homogenate containing ISAV. The 4 groups were kept in separate tanks, each including 10 non-inoculated cohabitants. The ISAV challenge of $60 \mathrm{IPNV}$ infected and 60 uninfected fish was repeated $8 \mathrm{wk}$ after the IPNV bath challenge.

The interference between a primary IPNV infection and a secondary Vibrio salmonicida infection during acute IPN was also studied in a second challenge test. In Expt 2, 200 smolts with an average weight of $52 \mathrm{~g}$ were bath challenged with IPNV, as described for Expt 1. Two hundred mock-infected controls were held in a separate tank. The experiment was run for $9 \mathrm{wk}$. IPNV titre tests were done 1, 3, 4 and 6 wk after IPNV challenge, as described for Expt 1. Three and $6 \mathrm{wk}$ after IPNV bath challenge 50 infected and 50 uninfected post-smolts were inoculated i.p. with $10^{5} \mathrm{~V}$. salmonicida $(0.5 \mathrm{ml})$ per fish and put in separate tanks, each including 10 non-inoculated cohabitants. Virus titres were determined in head kidney homogenates from dead fish infected with IPNV alone or with both IPNV and $V$. salmonicida to study whether $V$. salmonicida would affect the IPNV infection in terms of virus propagation.

The viral interference between a primary IPNV infection and a secondary ISAV infection during acute IPN was also studied in a second challenge test. In Expt 3, 200 unvaccinated post-smolts with an average weight of $100 \mathrm{~g}$ were bath challenged with IPNV, as in the previous 2 experiments. Two hundred mock infected controls were held in a separate tank. Three weeks after IPNV bath challenge, 43 infected fish and 50 uninfected control fish were inoculated i.p. with $0.5 \mathrm{ml}$ ISAV $\left(5 \times 10^{3}\right.$ i.u. $\left.\mathrm{ml}^{-1}\right)$ and put in separate tanks, each including 10 non-inoculated cohabitants. The experiment was run for $10 \mathrm{wk}$. IPNV titre tests were done on 6 IPNV-infected fish 1, 2, 3, 4 and $10 \mathrm{wk}$ after IPNV challenge and on 6 uninfected fish 1, 3 and $10 \mathrm{wk}$ after IPNV challenge, as described for Expt 1.

Virological identification. IPN was verified by reisolation and titration of IPNV from the head kidneys and pyloric caecae of dead or moribund fish. The lower IPNV detection level was $10^{2.25} \mathrm{TCID}_{50} \mathrm{~g}^{-1}$ tissue. In addition, IPNV was detected in pancreatic tissue by an immunohistochemical procedure mainly as described by Evensen \& Rimstad (1990). Rabbit antiserum against IPNV serotype Sp (produced at our laboratory) or the monoclonal antibodies anti-VP3 and anti-VP2 (kindly provided by K. E. Christie, Intervet Norbio Ltd, Bergen, Norway) were added to the sections as primary antibodies, while biotinylated swine anti-rabbit immunoglobulin (Ig) (DAKO) or biotinylated rabbit anti-mouse Ig (DAKO) was used as a secondary antibody. 
ISA was verified in dead fish by typical macroscopic signs of disease and by an indirect fluorescent antibody technique (IFAT) applied on liver and kidney imprints from 10 fish in each experiment using rabbit antiserum against ISAV (produced at our laboratory) followed by fluorescein isothiocyanate (FITC)-conjugated swine anti-rabbit Ig (DAKO).

Bacterial identification. Cold water vibriosis was verified by reisolation of Vibrio salmonicida in head kidney samples from dead fish on marine agar plates (oxoid agar). To ascertain the absence of any bacterial infections in fish infected with virus alone and any bacterial infections other than cold water vibriosis in $V$. salmonicida-infected fish, samples taken aseptically from head kidneys of all dead or sampled moribund fish were also inoculated onto blood agar (oxoid blood agar base no. 2 with $2 \%$ human red blood cells and $1.5 \% \mathrm{NaCl}$ ), brain heart infusion broth/Coomassie blue agar (BHI, Difco, in oxoid agar no. 3 supplemented with $0.005 \%$ Coomassie brilliant blue) and marine agar and incubated at $12^{\circ} \mathrm{C}$ for $3 \mathrm{~d}$. Single colonies were studied by microscopy and tested with diagnostic test kits containing antibodies against $V$. salmonicida, Vibrio anguillarum and Aeromonas salmonicida, subsp. salmonicida (Mono-Vs, -Va and As, BIONOR, Skien, Norway). Only bacteria belonging to the normal flora of the fish were occasionally detected.

The number of live fish sacrificed and sampled during the experiments was subtracted from the population to calculate cumulative moralities. The $\chi^{2}$-test was used for comparison of mortalities in 2 replicate tanks or in 2 groups of fish.

\section{RESULTS}

\section{Mortalities in the interference experiments}

Secondary infections during an acute stage of IPN (3 wk after IPNV bath challenge)

In Expt 1, mortality due to ISA in Atlantic salmon post-smolts previously exposed to IPNV was significantly less $\left(\mathrm{p}<0.001, \chi^{2}\right.$-test) than that in fish infected with ISAV alone. The cumulative mortalities in the 2 groups were 28 and $68 \%$, respectively (Fig. 1a). Cumulative mortality in the group infected with IPNV alone was $3 \%$ during the $13 \mathrm{wk}$ the whole trial lasted. The ongoing IPNV infection seemed to provide a protection against ISA. These results were confirmed in another ISAV challenge in Expt 3. This time the ISAV infection alone caused a cumulative mortality as high as $98 \%$, but still significantly fewer fish (73\%) died in the ISAV group previously exposed to IPNV ( $p<0.05$, $\chi^{2}$-test) (Fig. 1b). A total of $15 \%$ challenged with IPNV alone died during the whole trial.

Quite the opposite was observed after a secondary bacterial infection. In Expt 1, significantly more fish died after challenges with both IPNV and Vibrio salmonicida (38\%) than with $V$. salmonicida alone $(15 \%),\left(p<0.02, \chi^{2}\right.$-test) (Fig. 2a). Mortality also started earlier in the double infected group than in the group challenged with $V$. salmonicida alone, 4 and $8 \mathrm{~d}$ after $V$. salmonicida infection, respectively. These results were repeated in Expt 2, where cumulative mortality reached $77 \%$ in the double-infected group, versus $55 \%$ in the group challenged with V. salmoni- a ) experiment 1

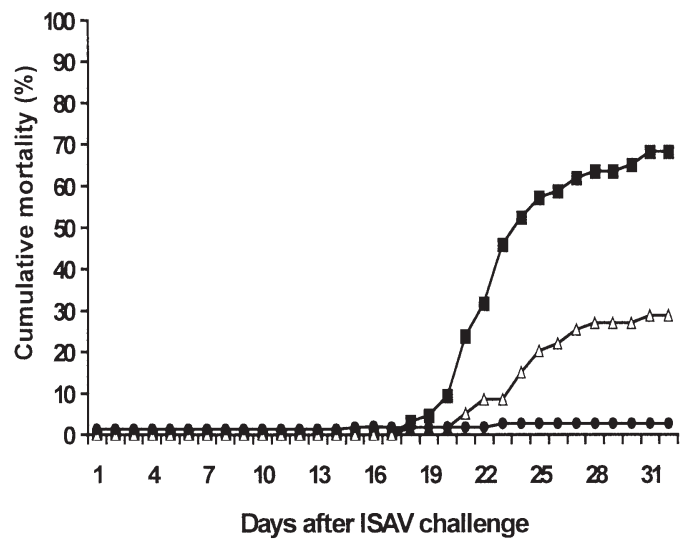

b) experiment 3

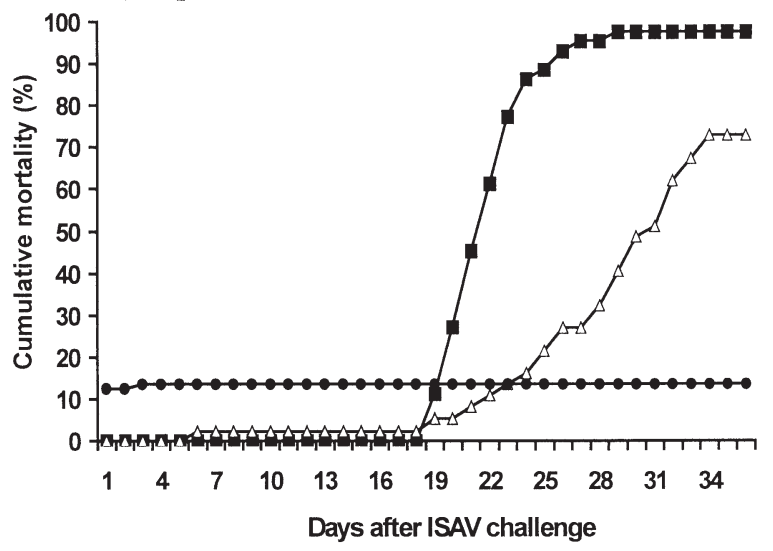

Fig. 1. Double infections with infectious pancreatic necrosis virus (IPNV) and infectious salmon anaemia virus (ISAV) in (a) Expt 1 and (b) Expt 3. In each experiment a group of fish was bath infected with IPNV (•). Three weeks later a group of these fish was additionally infected with ISAV by intraperitoneal injection $(\Delta)$. A third group was infected with ISAV alone (匹). The cumulative mortalities in the groups are compared 
a) experiment 1

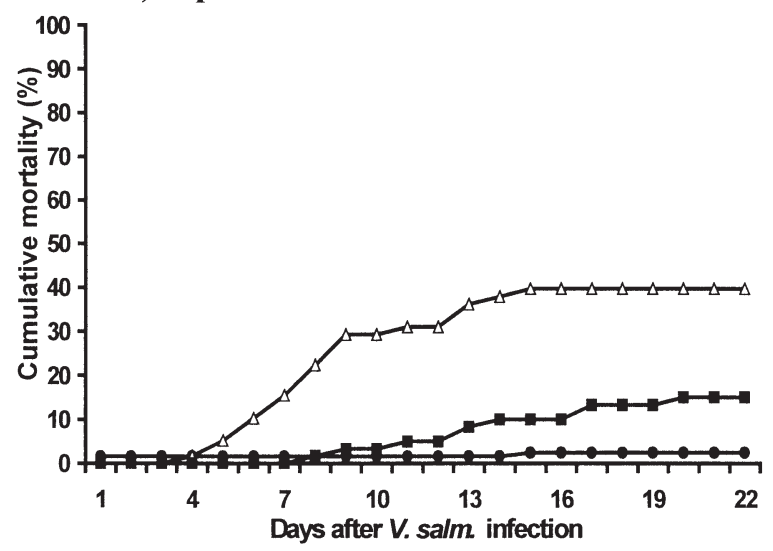

b) experiment 2

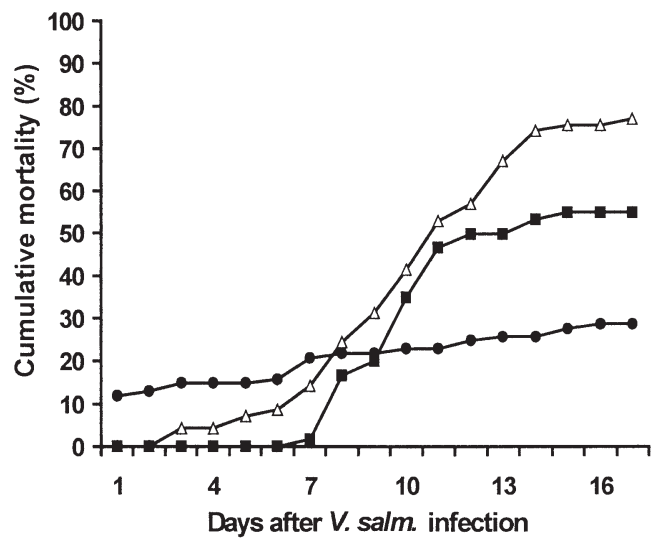

Fig. 2. Double infections with IPNV and Vibrio salmonicida (V. salm.) in (a) Expt 1 and (b) Expt 2. In each experiment a group of fish was bath infected with IPNV $(\bullet)$. Three weeks later a group of these fish was additionally infected with $V$. salmonicida by intraperitoneal injection $(\Delta)$. A third group of fish was infected with $V$. salmonicida alone (匹). Cumulative mortalities in the groups are compared

a) experiment 1

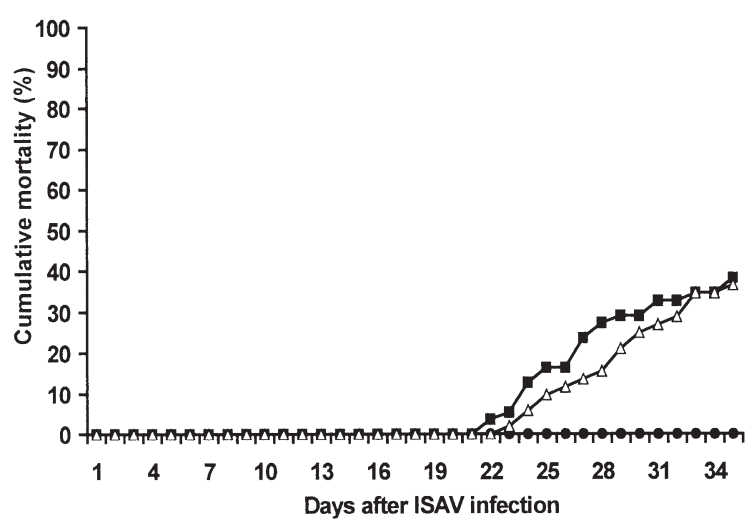

b) experiment 2

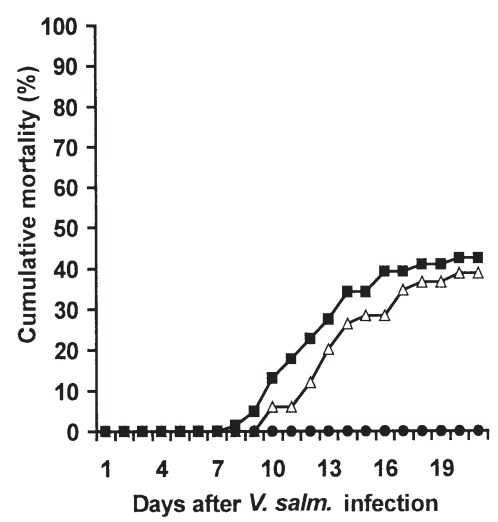

Fig. 3. IPNV carriers additionally infected with ISAV or Vibrio salmonicida in (a) Expt 1 and (b) Expt 2. In both experiments a group of Atlantic salmon was bath infected with IPNV $(\bullet)$. Expt 1: a group of the IPNV-infected fish was additionally infected with ISAV by intraperitoneal injection $6 \mathrm{wk}$ after the IPNV infection $(\Delta)$. A third group was infected with ISAV alone (घ). Expt 2: a group of the IPNV-infected fish was additionally infected with $V$. salmonicida 8 wk after the IPNV infection ( $\Delta$ ). A third group was infected with $V$. salmonicida alone $(\boldsymbol{\varpi})$. The cumulative mortalities in the groups are compared

cida alone ( $\mathrm{p}<0.02, \chi^{2}$-test) (Fig. 2b). As observed in the first experiment, mortality started in the double infected group at Day 3 after $V$. salmonicida infection, followed $5 \mathrm{~d}$ later in the group challenged with $V$. salmonicida. A total of $30 \%$ died in the groups infected with IPNV alone during the whole 9 wk trial, compared with $3 \%$ in Expt 1.

Secondary challenges during the IPNV carrier stage (6 to $8 \mathrm{wk}$ after IPNV bath challenge)

No significant differences in cumulative mortalities after secondary infections were observed between
IPNV-infected fish and IPNV-free fish (Fig. 3a,b). An experimental IPNV carrier condition was now established with low IPNV titres or no titres detected at all. No fish died due to IPN in this period.

\section{IPNV-challenged fish}

Overall, the IPNV infections in the 3 experiments developed quite similarly, even though some variations in titres and frequency of IPNV-positive fish were detected (Table 1). Some of the first samples taken $1 \mathrm{wk}$ after infection were IPNV positive, but the highest titres and the highest frequency of IPNV-posi- 
Table 1. Infectious pancreatic necrosis virus (IPNV) titres $\left(\log _{10}\right.$ of TCID $\left._{50} \mathrm{~g}^{-1}\right)$ in Atlantic salmon head kidneys 1 to $6 \mathrm{wk}$ after bath infection with IPNV in Expts 1, 2 and 3. The minimum detectable titre was $10^{2.25} \mathrm{TCID}_{50} \mathrm{~g}^{-1}$ tissue. 0 means $<2.25$; - not done

\begin{tabular}{|c|c|c|c|c|c|c|}
\hline \multirow{2}{*}{$\begin{array}{l}\text { Fish } \\
\text { no. }\end{array}$} & \multicolumn{6}{|c|}{ Weeks after infection } \\
\hline & 1 & 2 & 3 & 4 & 5 & 6 \\
\hline \multicolumn{7}{|c|}{ Expt 1} \\
\hline 1 & 3.00 & 0 & 0 & - & - & 0 \\
\hline 2 & 0 & 0 & 7.03 & - & - & 0 \\
\hline 3 & 3.90 & 3.90 & 2.36 & - & - & 0 \\
\hline 4 & 0 & 0 & 2.93 & - & - & 3.36 \\
\hline 5 & 0 & 5.23 & 3.20 & - & - & 0 \\
\hline 6 & 0 & 3.90 & 0 & - & - & 0 \\
\hline \multicolumn{7}{|c|}{ Expt 2} \\
\hline 1 & 0 & - & 0 & 5.27 & - & 0 \\
\hline 2 & 0 & - & 0 & 7.55 & - & 4.73 \\
\hline 3 & 0 & - & 4.27 & 6.73 & - & 7.30 \\
\hline 4 & 0 & - & 0 & 3.27 & - & 3.55 \\
\hline 5 & 0 & - & 5.73 & 0 & - & - \\
\hline 6 & 0 & - & 0 & 3.55 & - & - \\
\hline \multicolumn{7}{|c|}{ Expt 3} \\
\hline 1 & 2.50 & 3.50 & 4.50 & 4.50 & - & - \\
\hline 2 & 2.50 & 4.50 & 5.33 & 0 & - & - \\
\hline 3 & 3.57 & 2.50 & 5.67 & 4.50 & - & - \\
\hline 4 & 0 & 3.50 & 0 & 3.33 & - & - \\
\hline 5 & 0 & 0 & 5.50 & 0 & - & - \\
\hline 6 & 0 & 5.50 & 5.50 & 3.67 & - & - \\
\hline
\end{tabular}

tive samples occurred 3 to 4 wk after IPNV challenge in all the experiments. By Week 6 after infection the titres had decreased markedly, but IPNV was still detected in some of the samples. In Expt 3 all samples taken 10 wk after IPNV challenge were IPNV negative (results not shown). The cumulative mortality due to IPN differed in the 3 experiments: $3 \%$ died in Expt 1, 30\% in Expt 2 and 15\% in Expt 3 (Figs 1 to 3). Fish dead after the IPNV challenges had petheciae in the pyloric caecae, empty stomachs, ascites in their body cavities and a milky cohesive mucus in the anterior intestine. Hearts, livers and spleens were generally pale. Fish that were killed after Day 21 of the experiments also had some or all of these signs of disease. Fish that died due to acute IPN had IPNV titres varying between $10^{6}$ and $10^{8} \mathrm{TCID}_{50} \mathrm{~g}^{-1}$ tissue (Table 2), and no bacterial pathogens were detected. By immunostaining, massive amounts of IPNV were detected in areas of degenerating and necrotic pancreatic tissue from moribund or dead fish (results not shown). This was not found in uninfected control fish or in pancreatic tissue from fish infected with ISAV, used as control. No uninfected control fish died during the 3 experiments and no IPNV carriers were detected.
Table 2. IPNV titres $\left(\log _{10}\right.$ of $\mathrm{TCID}_{50} \mathrm{~g}^{-1}$ tissue) in head kidneys collected from Atlantic salmon in Expt 2. Group A: titres detected in fish dead after experimental infection with IPNV alone. Group B: titres in dead IPNV-infected fish challenged with Vibrio salmonicida 3 wk after the IPNV infection. Group C: titres of survivers from Group A 6 wk after the IPNV infection. Group D: titres of survivers from Group B 6 wk after the IPNV infection. Head kidneys were isolated, homogenised and end-point titrated in 6 to 8 parallels in 96-well cell culture plates with CHSE-214 cells. After 1 wk of incubation the cytopathic effect was read and TCID $_{50}$ titres calculated. The minimum detectable titre was $10^{2.25} \operatorname{TCID}_{50} \mathrm{~g}^{-1}$ tissue. 0 means $<2.25$; not done

\begin{tabular}{|lcccc|}
\hline Fish no. & Group A & Group B & Group C & Group D \\
\hline 1 & 8.27 & 5.70 & 0 & 2.25 \\
2 & 6.60 & 0 & 4.73 & 3.69 \\
3 & 5.55 & 5.93 & 7.30 & 0 \\
4 & 6.27 & 4.87 & 3.55 & 0 \\
5 & 5.55 & 3.70 & 0 & 0 \\
6 & 6.55 & 4.70 & 0 & 0 \\
7 & 5.55 & 5.70 & 0 & 0 \\
8 & 7.55 & 6.20 & 3.36 & 0 \\
9 & - & 6.20 & 0 & 3.27 \\
10 & - & 4.20 & 0 & 0 \\
11 & - & 0 & - & 3.27 \\
12 & - & 3.25 & - & 4.39 \\
13 & - & - & - & 4.39 \\
14 & - & - & - & 0 \\
\hline
\end{tabular}

\section{Vibrio salmonicida- and ISAV-challenged fish}

Vibrio salmonicida was isolated from head kidneys of all fish that died after $V$. salmonicida challenges, and the fish had the typical macroscopic signs of a cold water vibriosis infection: petechiae in the skin and at the basis of the fins, enlarged yellow liver and a yellow fluid in the intestine. In Expt 2 the IPNV titres detected in dead fish secondarily infected with $V$. salmonicida during acute IPN were lower overall than those in fish that died after the IPNV infection alone (Table 2), and 2 samples were IPNV negative. The same situation was seen when the secondary infection with $V$. salmonicida was done in an IPNV carrier stage. In fact, in this period IPNV was not detected in 8 of 14 dead double-infected fish. This showed that the secondary $V$. salmonicida infection did not reactivate the IPNV infection in terms of increasing IPNV titres.

Fish that died after ISAV challenges showed the macroscopic changes typical of acute ISA, with pale gills and heart and low haematocrit values due to anaemia, a dark, haemorrhagic liver, petechiae in perivisceral fat and massive amounts of ascites in the body cavity. In addition, ISAV was detected by indirect fluorescent antibody technique in all liver and kidney imprints examined (results not shown). 


\section{DISCUSSION}

Because of the common IPNV carrier condition and the increase in IPN-related problems in post-smolts over the last several years, it is important to attain more knowledge about different aspects of IPNV infections. The present study shows that an IPNV carrier condition at low virus titre does not influence the mortality rates after secondary infections. Neither an ISAV infection nor a Vibrio salmonicida infection in experimentally induced IPNV carriers resulted in mortalities different from those observed after challenge of IPNVfree fish. The virus titres and frequency of IPNV-positive fish detected 6 to $8 \mathrm{wk}$ after IPNV challenge were consistent with those reported from natural IPNV carrier conditions in salmonid fish (Yamamoto 1975, Hedrick \& Fryer 1982). Similar virus titres were also observed $6 \mathrm{wk}$ after IPNV challenge in individuals that had been secondarily infected with $V$. salmonicida 3 wk earlier. No indication of IPNV reactivation due to the bacterial infection was found. In fact IPNV could not be detected in many of the double-infected fish, but more extensive virus titre studies are needed before any final conclusions can be drawn. We did not investigate the IPNV titres in fish double infected with IPNV and ISAV, but Melby \& Falk (1995) have reported that an ISAV infection did not affect a natural IPNV carrier condition in Atlantic salmon with respect to virus titre development and specific IPNV antibody production. Recently, Damsgård et al. (1998) reported that feed intake and growth in Atlantic salmon were not influenced by low IPNV titres. These reports support our observations that an IPNV carrier condition at low virus titre in the Atlantic salmon does not seem to have a measurable negative impact on the general health of the fish and thus on their susceptibility to diseases. Nevertheless, it cannot be concluded that the commonly observed IPNV carrier condition among Atlantic salmon presents no risk to fish health. A reactivation of IPNV causing outbreaks of IPN after transfer to seawater may be initiated by different forms of environmental stress, such as transport, handling, crowding, temperature or salinity shock (Roberts \& McKnight 1976, Stangeland et al. 1996), none of which has been studied in our experiments. Furthermore, it is observed that during an IPNV carrier condition the amount of virus may fluctuate from not detectable to relatively high titres (Hedrick \& Fryer 1982).

At higher IPNV titres in Atlantic salmon with acute IPN we have shown that the outcome of secondary infections is quite different from that observed in IPNV-free fish and in IPNV carriers. Significantly more fish died when fish with acute IPN were infected with Vibrio salmonicida than when fish that where infected with $V$. salmonicida alone. Similar results were ob- served in 2 different experiments, independent of whether mortalities due to IPN were registered in the experiments. This shows that the increased mortality was not just a result of adding up the individual mortalities due to the 2 different pathogens, but rather it suggests a mutual role in disease development. We did not study the cause of mortality using methods that can correlate the presence of either of the 2 agents to specific pathological lesions, but both pathogens were detected in samples from dead fish. Besides increasing the cumulative mortality, double infections with IPNV and bacteria may limit the effect of treatment with antibiotics because Atlantic salmon showing high IPNV titres generally have poor appetite, as shown by Damsgård et al. (1998).

The mechanisms behind interactions between viral and bacterial infections in a host are complex and not well understood. Invading bacteria elicit a respiratory burst response in fish phagocytes and the ability to kill Aeromonas salmonicida has been correlated to an enhanced capacity to produce reactive oxygen species (Graham et al. 1988). Phagocytes may also serve as host cells for different viruses. IPNV infection and replication in leukocytes from salmonids has been reported (Yu et al. 1982, Knott \& Munro 1986, Johansen \& Sommer 1995b). We have previously reported that cultures of head kidney macrophages isolated from Atlantic salmon show reduced ability to produce intracellular $\mathrm{O}_{2}{ }^{-}$after infection by IPNV in vitro (Johansen \& Sommer 1995a). In preliminary studies we have also shown that the $\mathrm{O}_{2}^{-}$production in head kidney macrophages isolated from IPNV carriers is not reduced compared with IPNV-free controls, while the ability to produce $\mathrm{O}_{2}^{-}$in macrophages isolated from fish with acute IPN is reduced (unpubl.). The decreased $\mathrm{O}_{2}^{-}$production, and thereby antibacterial defence, may be one explanation for why fish with acute IPN have increased mortality compared with IPNV carriers and IPNV-free fish, when infected with V. salmonicida.

Our results clearly show that there are different defence mechanisms in action against viral or bacterial infections in the Atlantic salmon. When fish with acute IPN where challenged with ISAV, we observed a significantly reduced mortality compared with the group infected with ISAV alone. Similar results were observed in 2 different experiments using varying ISAV infectivity, independent of different mortalities due to IPN in the 2 experiments. Our preliminary results show that serum components isolated from fish with acute IPN have anti-viral properties (unpubl.). It is well documented that fish produce interferon (IFN) or IFN-like agents in response to different viral infections including IPNV, and that the IFN production coincides with virus multiplication (de Kinkelin \& Dorson 1973, 
Dorson et al. 1992, Hedrick et al. 1994, Chinchar et al. 1998). If IFN is the main cause of the protection against ISAV found in our study, these reports support the observations that only fish with acute IPN, i.e., actively producing IPNV, were protected against ISAV. However, unspecific immunological responses can be caused by several factors other than IFN. In vitro studies of double infections with different fish viruses have revealed some possible mechanisms behind such virus infections in fish (Chinchar et al. 1998, Alonso et al. 1999), but still little is known about how the fish deal with different double infections and what consequences they may have for the fish.

Acknowledgements. This study was financially supported by the Norwegian Research Council. We wish to thank Ms S. Mennen for excellent technical assistance.

\section{LITERATURE CITED}

Alonso M, Rodrìguez S, Pèrez-Prieto SI (1999) Viral coinfections in salmonids: infectious pancreatic necrosis virus interferes with infectious hematopoietic necrosis virus. Arch Virol 144:657-673

Blackburn J, Clarke WC (1987) Revised procedure for the 24 hour seawater challenge test to measure seawater adaptability of juvenile salmonids. Can Tech Rep Fish Aquat Sci 1515:1-35

Chinchar VG, Logue O, Antao A, Chinchar GD (1998) Channel catfish reovirus (CRV) inhibits replication of channel catfish herpesvirus (CCV) by two distinct mechanisms: viral interference and induction of an anti-viral factor. Dis Aquat Org 33:77-85

Damsgård B, Mortensen A, Sommer AI (1998) Effects of infectious pancreatic necrosis virus (IPNV) on appetite and growth in Atlantic salmon, Salmo salar L. Aquaculture 163:185-193

de Kinkelin P, Dorson M (1973) Interferon production in rainbow trout (Salmo gairdneri) experimentally infected with Egtved virus. J Gen Virol 19:125-127

de Kinkelin P, Dorson M, Renault T (1992) Interferon and viral interference in viroses of salmonid fish. In: Kimura $\mathrm{T}$ (ed) Proceedings of the OJI International Symposium on Salmonid Diseases. Hokkaido University Press, Sapporo, p 241-249

Dorson M, Torchy C (1981) The influence of fish age and water temperature on mortalities of rainbow trout, Salmo gairdneri Richardson, caused by a European strain of infectious pancreatic necrosis virus. J Fish Dis 4:213-221

Dorson M, de Kinkelin P, Torchy C (1992) Interferon synthesis in rainbow trout fry following infection with infectious pancreatic necrosis virus. Fish Shellfish Immunol 2: 311-313

Evensen Ø, Lorenzen E (1997) Simultaneous demonstration of infectious pancreatic necrosis virus (IPNV) and Flavobacterium psychrophilum in paraffin-embedded specimens of rainbow trout Oncorhynchus mykiss fry by use of paired immunohistochemistry. Dis Aquat Org 29:227-232

Evensen Ø, Rimstad E (1990) Immunohistochemical identification of infectious pancreatic necrosis virus in paraffinembedded tissues of Atlantic salmon (Salmo salar). J Vet Diagn Invest 2:288-293
Graham S, Jeffries AH, Secombes CJ (1988) A novel assay to detect macrophage bactericidal activity in fish: factors influencing the killing of Aeromonas salmonicida. J Fish Dis 11:389-396

Hedrick RP, Fryer JL (1982) Persistent infections of salmonid cell lines with infectious pancreatic necrosis virus (IPNV): a model for the carrier state in trout. Fish Pathol 16: 163-172

Hedrick RP, LaPatra SE, Yun S, Lauda KA, Jones GR, Congleton JL, de Kinkelin P (1994) Induction of protection from infectious hematopoietic necrosis virus in rainbow trout Oncorhynchus mykiss by pre-exposure to the avirulent cutthroat trout virus (CTV). Dis Aquat Org 20:118-124

Hetrick FM (1989) Fish viruses. In: Austin B, Austin DA (eds) Methods for the microbiological examination of fish and shellfish. Ellis Horwood Ltd, Chichester, p 216-239

Jarp J, Gjevre AG, Olsen AB, Bruheim T (1994) Risk factors for furunculosis, infectious pancreatic necrosis and mortality in post-smolt of Atlantic salmon, Salmo salar L. J Fish Dis 18:67-78

Johansen LH, Sommer AI (1995a) In vitro studies of infectious pancreatic necrosis virus infections in leukocytes isolated from Atlantic salmon (Salmo salar L.). Aquaculture 132: 91-95

Johansen LH, Sommer AI (1995b) Multiplication of infectious pancreatic necrosis virus (IPNV) in head kidney and blood leukocytes isolated from Atlantic salmon, Salmo salar L. J Fish Dis 18:147-156

Knott RM, Munro ALS (1986) The persistence of infectious pancreatic necrosis virus in Atlantic salmon. Vet Immunol Immunopathol 12:359-364

Krogsrud J, Håstein T, Rønningen K (1989) Infectious pancreatic necrosis virus in Norwegian fish farms. In: Ahne W, Kurstak E (eds) Viruses of lower vertebrates. Springer Verlag, Berlin, p 284-291

Lannan CN, Winthon JR, Fryer JL (1984) Fish cell lines: establishment and characterization of nine cell lines from salmonids. In Vitro 220:671-676

La Patra SE, Lauda KA, Woolley MJ, Armstrong R (1993) Detection of naturally occurring coinfection of IHNV and IPNV in rainbow trout. Am Fish Soc/Fish Health Sect Newsl 21:9-10

LaPatra SE, Lauda KA, Jones GR (1995) Aquareovirus interference mediated resistance to infectious hematopoietic necrosis virus. Vet Res 26:455-459

Lee KK, Yang TI, Liu PC, Wu JL, Hsu YL (1999) Dual challenges of infectious pancreatic necrosis virus and Vibrio carhariae in the grouper, Epinephelus sp. Virus Res 63: 131-134

Lovely JE, Dannevig BH, Falk K, Hutchin L, MacKinnon AM, Melville KJ, Rimstad E, Griffiths SG (1999) First identification of infectious salmon anaemia virus in North America with haemorrhagic kidney syndrome. Dis Aquat Org 35: 145-148

Melby HP, Falk K (1995) Study of the interaction between a persistent infectious pancreatic necrosis virus (IPNV) infection and experimental infectious pancreatic salmon anaemia (ISA) in Atlantic salmon, Salmo salar L. J Fish Dis 18:579-586

Melby HP, Krogsrud J, Håstein T, Stenwig H (1991) All commercial Atlantic salmon seawater farms in Norway harbour carriers of infectious pancreatic necrosis virus (IPNV). In: Fryer JL (ed) Proceedings from the 2nd International Symposium on Viruses of Lower Vertebrates. Oregon State University, Corvallis, p 211-217

Mjaaland S, Rimstad E, Falk K, Dannevig BH (1997) Genomic characterization of the virus causing infectious salmon 
anaemia in Atlantic salmon (Salmo salar L.): an orthomyxo-like virus in a teleost. J Virol 71:7681-7686

Mulchahy DM, Fryer JL (1976) Double infection of rainbow trout fry with IHN and IPN viruses. Am Fish Soc/Fish Health Sect Newsl 5:5-6

Nicholson BL, Byrne C (1973) An established cell line from Atlantic salmon (Salmo salar). J Fish Res Board Can 30: 913-916

Reed JL, Muench H (1938) A simple method for estimating fifty percent end points. Am J Hyg 27:493-497

Roberts RJ, McKnight IJ (1976) The pathology of infectious pancreatic necrosis virus. II. Stress-mediated recurrence. Br Vet J 132:209-213

Rowley HM, Campbell SJ, Curran WL, Turnbull T, Bryson DG (1999) Isolation of infectious salmon anaemia virus (ISAV) from Scottish farmed Atlantic salmon, Salmo salar L. J Fish Dis 22:483-487

Smail DA, Bruno DW, Dear G, McFarlane LA, Ross K (1992) Infectious pancreatic necrosis (IPN) virus $\mathrm{Sp}$ serotype in

Editorial responsibility: Jo-Ann Leong,

Corvallis, Oregon, USA farmed Atlantic salmon, Salmo salar L., post-smolts associated with mortality and clinical disease. J Fish Dis 15:77-83

Snieszko SF, Wolf K, Camper JE, Pettijohn LL (1959) Infectious nature of pancreatic necrosis. Trans Am Fish Soc 88: 289-293

Sommer AI, Mennen S (1997) Multiplication and haemadsorbing activity of infectious salmon anaemia virus in the established Atlantic salmon cell line. J Gen Virol 78: 1891-1895

Stangeland K, Høie S, Taksdal T (1996) Experimental induction of infectious pancreatic necrosis in Atlantic salmon, Salmo salar L., post-smolts. J Fish Dis 19:323-327

Yamamoto T (1975) Infectious pancreatic necrosis (IPN) virus carriers and antibody production in a population of rainbow trout (Salmo gairdneri). Can J Microbiol 21: 1343-1347

Yu KKY, Macdonald RD, Moore AR (1982) Replication of infectious pancreatic necrosis virus in trout leukocytes and detection of the carrier state. J Fish Dis 5:401-410

Submitted: May 7, 2001; Accepted: August 16, 2001

Proofs received from author(s): October 22, 2001 